\title{
John C. Cantwell (1859-1940) and the Kobuk (Kowak) River, Alaska
}

The year 2009 is among our most famous anniversaries: it represents both the 200th year since Charles Darwin's birth and the 150th since Darwin's publication of On the Origin of Species. Interestingly, it is also the 150th anniversary of the birth of Captain John Cassin Cantwell, one of the earliest explorers of Northwest Alaska.

John Cassin Cantwell, born on 9 January 1859, was only eight years old when Alaska was purchased from Russia in 1867. Little did he know that this new territory and its waters would come to dominate his life. He was born into a well-educated, politically oriented, military family that earlier had emigrated from Ireland. His father, who had a law degree from Harvard, was a colonel in the Army and the author of a number of books on law and history. The family being Catholic, it is not surprising that young John was sent to a Roman Catholic seminary in Ireland. According to his grandson, John's “education was designed to make him a priest - all of the years in Ireland he was unhappy and vowed that he would return to the U.S.A, ...which he did. Having a fine education he wanted to be a sailor" (Burnham Cantwell, pers. comm. 1982).

Following through on that desire, Cantwell enlisted at age 20 in the United States Revenue Cutter Service (USRCS) with the intention of becoming a career officer. After serving for a year as a seaman, he took and passed a competitive examination that in turn led to a commission as Third Lieutenant on 5 July 1882. The USRCS, an arm of the Treasury Department, had been formed in 1790 to collect customs along the coasts of the newly formed United States of America. Until 1863, it had officially been known as the United States Revenue Marine. Although in 1915 it was merged with other marine-related services to become the U.S. Coast Guard, it was the USRCS that dominated the government's marine and riverine activities in Alaska, especially those in the Bering Sea, during the early days of Cantwell's career.

The sine qua non of the Service was the cutter, originally a small, single-masted, lightly armed ship that was fast and especially useful in coastal waters. Through the years cutters were continually modified, and by the time of Cantwell, many were steam-powered.

After a couple of years sailing with cutters along the East and Gulf Coasts of the United States, Cantwell was sent to San Francisco in 1884. There he was assigned to the cutter Thomas Corwin under the command of Captain Michael A. Healy (after whom the present USCGC Healy is named). From the standpoint of Cantwell's adventuresome spirit, this assignment was fortuitous: the Corwin was the first cutter to cruise regularly in the Bering Sea, and Healy was the ideal mentor for someone with Cantwell's ambitions. In fact, as John Murphy (1968:12) wrote, "From Healy, Cantwell learned the difference between audacity and foolhardy courage and the short distance that separates proper caution from paralyzing fear of the elements." They were

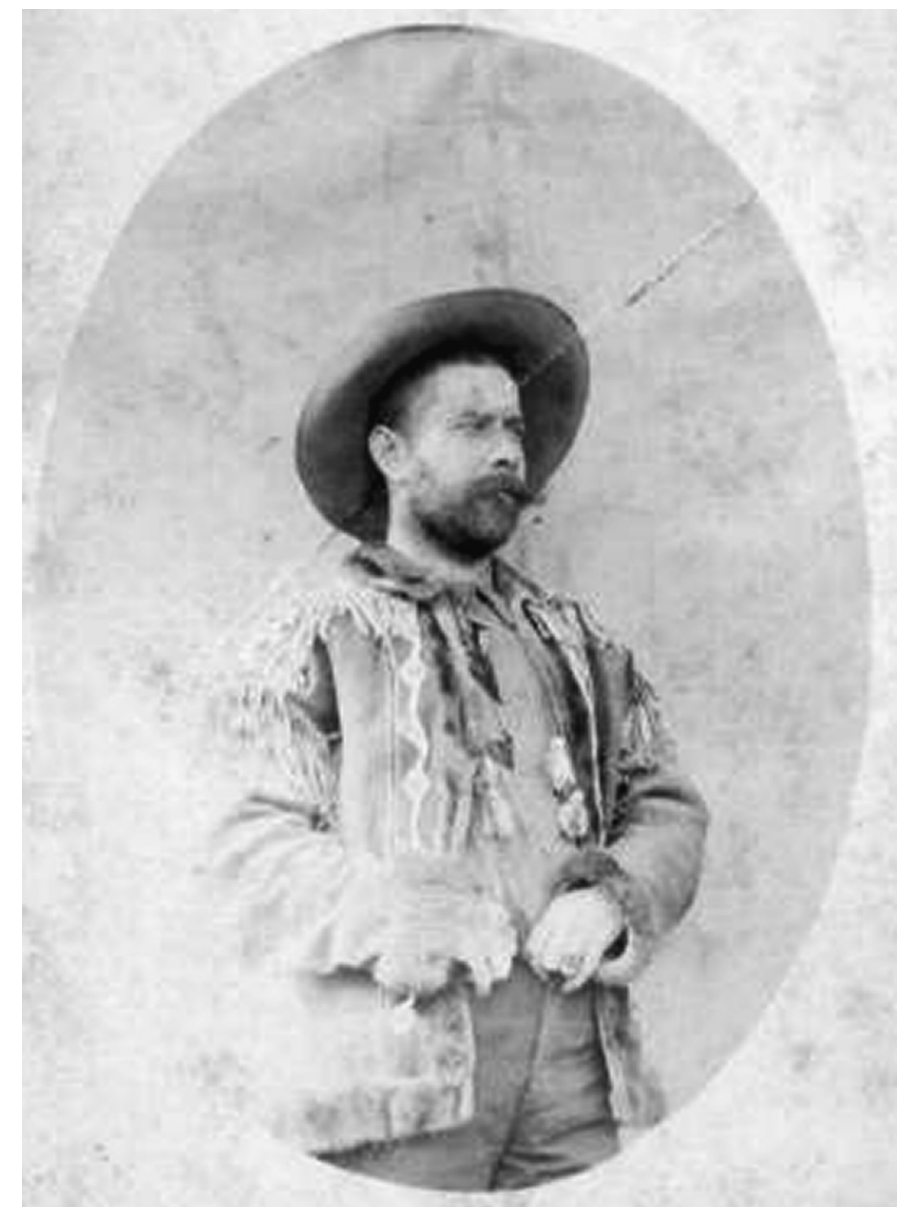

FIG. 1. John Cantwell on the Kobuk, age 25. Photo courtesy of Thomas W. Bentham photographs, Archives and Special Collections, Consortium Library, University of Alaska Anchorage.

lessons that served Cantwell well during the years he spent in the Arctic.

Healy, who had been sailing Alaskan waters since 1874 (beginning less than 10 years after Alaska was purchased), took command of the Corwin in 1884, with Cantwell on board. By that time Healy and other cutter captains, during their routine and rescue patrols, had surveyed much of the shoreline of the Bering Sea and the Alaskan Arctic coast. During 1884 and 1885, the years Healy and Cantwell were on board, the Corwin "launched the longest and most extensive explorations ever conducted by cuttermen on Bering Sea Patrol" (Strobridge and Noble, 1999:81).

The circumstances that made it possible for Cantwell to become the RCS explorer of the Kowak River (later to become known as the Kobuk) are an excellent example of being in the right place at the right time. The delta and the lower reaches of the Kowak had been surveyed in 1883 by Lt. George M. Stoney while he was representing the Navy on the cutter Healy captained. As a result of the information gained by Stoney, Healy theorized that the Kowak, if it could be followed to its headwaters, might provide an 
escape route for whalers, who were often stranded along the Arctic coast near Barrow when their vessels became trapped in sea ice. Healy proposed and received Treasury Department approval to make a survey of the river system during his 1884 patrol of the Bering Sea. Thus, when the Corwin reached Cape Krusenstern, Healy dispatched his exploration team. The cutterman who was to head the team was injured while preparing for the task so, as Healy wrote, "Mr. Cantwell being available, I placed him in charge" (Healy, 1889:10). For the 25-year-old Cantwell, it was the opportunity of a lifetime. The orders given him stated, in part, "The Department [Treasury] desiring to ascertain the extent of the Kowak River, together with the character of the country..., the number, condition, habits, and customs of the inhabitants, and, in general, everything of interest to science and commerce, ...proceed to the mouth of the said river and begin the compilation of data." His orders also charged him with making "as accurate a survey of the river as possible with the instruments furnished" (Cantwell, 1889a:49).

Cantwell's crew consisted of an engineer, who was charged with collecting plants and animals; a "practical" miner, who was to be given "every opportunity for prospecting the country" (Cantwell, 1889a:49); and three others. On the second day out, another guide named Natorak, who proved indispensible to Cantwell, was sent to join them. Transportation consisted of the Corwin's steam launch and two small boats that were to be towed behind the launch when possible. The launch gave trouble throughout the 54-day trip. Since it was summer (July and August), frequent rainstorms, high temperatures, and mosquitoes further complicated the progress of the mission. Cantwell's report is a very detailed day-to-day account of the expedition (Cantwell, 1889a), with typical comments such as the following: 10 July (p. 54) "At 8 o'clock we pitched our tent on the right bank, and were immediately attacked by myriads of mosquitoes, which seemed to be of the most malignant disposition"; 18 July (p. 57) "We were detained as usual this morning by a heavy rain"; 20 July (p. 58) "Our advance to-day was varied by a season of rest from mosquitoes, but we had to submit to a lesser evil in the form of a violent rain-storm"; and 30 July (p. 63) "At one moment exposed to the burning heat of the summer sun, and the next floundering, plunging, and struggling waist-deep in dark pools of stagnant water." Despite such torments, Cantwell maintained his awe of nature and often waxed poetic (Cantwell, 1889a): 13 July (p. 55) "We experienced much trouble in keeping steam....[then] we ran into a reach..., and the vista was one of surpassing loveliness"; 15 August (p. 69) "The soft rays of the moon bathed lake, plain, and distant mountains in a flood of silvery light, and the air was filled with sweet perfume wafted to us from the rich tundra plains."

Cantwell was constantly taking measurements with his sextant and artificial horizon, weather permitting. He kept detailed notes about the river (width, depth, current, sand bars, shoals, bank types, and vegetation). Interest in vegetation was not entirely academic; the explorers needed wood

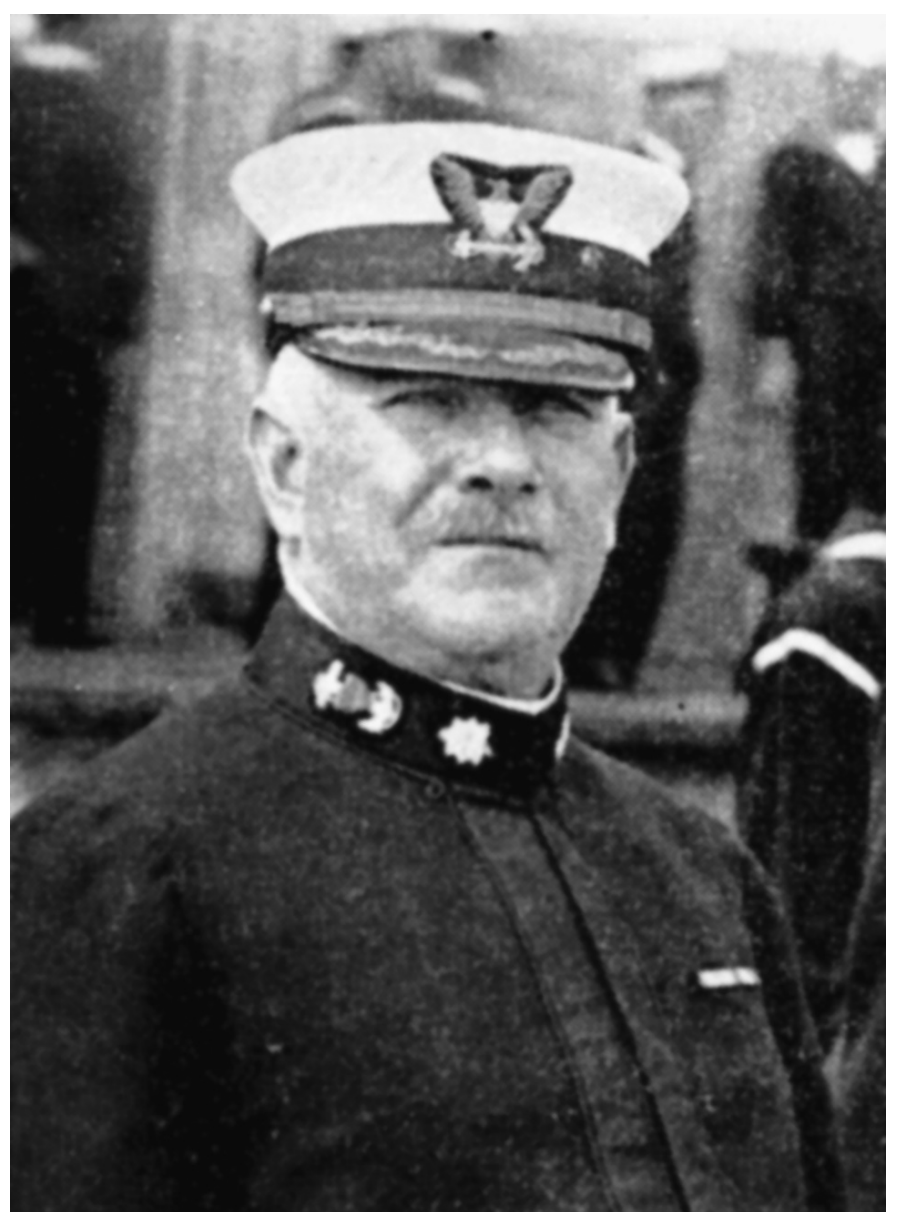

FIG. 2. John Cantwell as Commander in the USRMS, age about 50. Photo courtesy of the USCGA Library, U.S. Coast Guard Academy, New London, Connecticut.

for the steam launch. On the eighth day, they discovered coal in the riverbank, which proved useful; however, since storage space on board was limited, they soon ran out of coal and had to go back to wood. One of their most interesting discoveries occurred on 24 July, when they passed an undercut clay bluff "abound" with mammoth tusks. A major objective, written into the orders by Healy, was to follow up on the "rumored" existence of a Jade Mountain. On 21 July, Cantwell sent the engineer and the miner to explore the mountain. They brought back specimens of jade, as did Cantwell when he visited the mountain seven days later. To this day, Jade Mountain retains some of its mysterious nature.

Cantwell not only took to heart the charge of ascertaining "the number, condition, habits, and customs of the inhabitants" (Cantwell, 1889a:49), but also seemed to relish it. On 27 July, the party arrived at a village and "were welcomed with many manifestations of delight. Some of the Indians had never seen white men, and they crowded around me examining my clothing" (Cantwell, 1889a:54). They visited many villages and over the course of the expedition were assisted by numerous Indians. Cantwell's feelings toward them are exemplified by the statement that on 14 August "at 7:30 we bade farewell to our kind Indian friends" (Cantwell, 


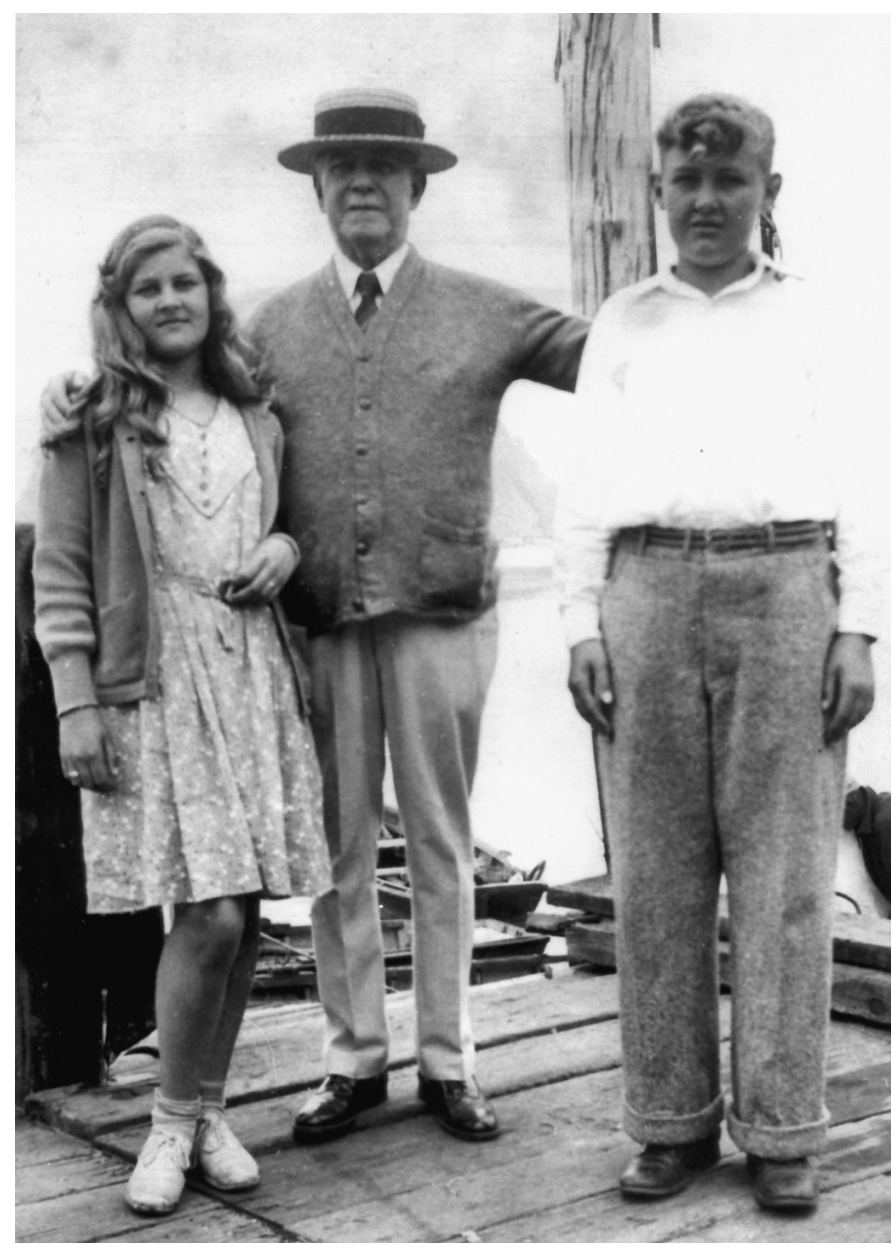

FIG. 3. John Cantwell at age 76 or 77 , with two of his three grandchildren. Photo courtesy of Ruth Cantwell, his daughter-in-law.

1889a:69). In addition to this narrative, Cantwell also produced "Ethnological Notes," which included details about weapons, hunting, fishing, festivals, personal habits, and adornment, supplemented with detailed drawings. After declaring that he felt "the natural hesitation of an inexperienced observer to advance any new theories," he went on to state his desire to describe "as simply as possible the characteristic features of the natives" (Cantwell, 1889b:77). For example, in describing the work habits of the Indians, he noted that women are "the only creatures of the body politic (not even excepting the dogs) who have no season of rest" (Cantwell, 1889b:80). In his introduction, Cantwell stated that he believed he had "obtained data in regard to these people which, if not all new, is at least reliable, and will furnish available matter for filling in a portion of the blank space on the ethnological chart of Alaska" (Cantwell, 1889b:77).

Despite the vagaries of the steam launch, weather (rain and temperatures in the 90s), difficult river conditions, and mosquitoes, Cantwell was able to ascend the river for $595 \mathrm{~km}$ (370 miles). In addition, because he was forced to return to Kotzebue Sound several days early, he was able to make a survey of Selawik Lake, which involved $330 \mathrm{~km}$ (205 miles) of travel in a light skin boat. Nonetheless,
Cantwell considered the expedition a failure because he did not reach the head of the river. That objective was not to be realized until the following year (1885), when Captain Healy and the Treasury again supported Cantwell in his quest.

This second expedition was quite different. The steam launch had been repaired and modified so that the party was able to reach its 1884 upstream limit in six days. The 1885 team included Charles Townsend, a Smithsonian Institution naturalist. Townsend happened to be conducting research on St. Paul's Island when the Corwin called there on its way north. Healy took him on board and assigned him to Cantwell. The addition of a trained scientist to the 26-yearold Cantwell's team "ensured the scientific success of the Corwin's second exploration up the Kobuk River" (Strobridge and Noble, 1999:91).

Despite improved equipment, the team experienced the same type of weather (hot and rainy), number of mosquitoes, and river obstacles as endured in 1884. They did experiment with a "thick varnish made of tar, gum Arabic, and olive oil; but even with this disagreeable preventive our sufferings were simply indescribable" (Cantwell, 1887:27). By the twelfth day, they reached a cataract above which the steam launch could not proceed. Cantwell decided to press on with the $8.5 \mathrm{~m}$ (28-foot) skin boat he called Pioneer. He left Townsend behind, along with two of the crew, with instructions to use the launch in pursuit of Townsend's research.

Ingenuity, hard work, and his Indian assistants were the main ingredients of Cantwell's success in reaching the lake the Indians had described as being the headwaters of the Kobuk. Upon seeing it, he wrote, "the sensations of pleasure and triumph which took possession of me as I gazed upon its waters, now for the first time seen by a white man, amply repaid me for the long, tedious journey" (Cantwell, 1887:37). The actual head of the river, however, was still farther up a narrow stream; they pushed the boat (which drew only $13 \mathrm{~cm}$ ) until it would no longer float. The stream had turned into "a shallow brawling brook, tumbling down between rugged mountains," a section they did not ascend (Cantwell, 1887:39).

Their trip downriver, though not without its difficulties, was somewhat anticlimactic. When Cantwell reached the place where they had left the launch, Townsend assured him that many "valuable specimens of the natural history of the country had been collected" (Cantwell, 1887:41). Several stops were made while going downriver in order for Cantwell to take measurements and Townsend to collect more samples. Cantwell also delved a bit into geomorphology; for example, he described river meandering and the development of ox-bow lakes (although he did not use those terms), and he puzzled over the origin of the "solid ice" that was exposed when riverbanks collapsed along parts of the channel. On 3 August, Cantwell and crew rejoined the Corwin, from which they had departed on 2 July.

The exploration of the Kowak (Kobuk) River is the dominant exploratory achievement of Cantwell, but he is 
also notable for other Arctic-related activities. For example, he was the first to make a survey of the New Bogoslov volcano that began to form in 1883 (Cantwell and Yemans, 1889). He added to the debate that was being waged about ice-cliffs during the beginning of the 20th century (Cantwell, 1896) and was a key player in getting reindeer established in Alaska (Cantwell, 1935). And, while Captain of the Revenue Steamer Nunivak in 1899-1901, he sent out exploratory teams from the Yukon River, some during winter (Cantwell, 1902). His 1902 report was declared "one of the finest books ever written about Alaska" by the explorer General Adolphus Greely (Frantz, 1940:2). Between 1884 and 1901, Cantwell's activities were mostly in the Arctic, usually with the RCS's Bering Sea Fleet.

Although Cantwell's life was dedicated to the U.S. Revenue Cutter Service, he did have a married life. His wife, a San Francisco socialite, usually remained in the San Francisco Bay area while Cantwell was serving elsewhere. Nonetheless, she played a major role in his West Coast activities, which included lecturing about Alaskan matters. They produced one son, who in turn had three children, the oldest of whom furnished the quotation used at the beginning of this paper. Cantwell rose through the ranks of the Service. He had aspirations of becoming Commandant, but that was never to be. Cantwell died in 1940, and in keeping with his desires, he was buried at sea.

\section{POSTSCRIPT}

Although credit goes to Cantwell for being the first to travel the length of the Kobuk, he had competition during both 1884 and 1885. As mentioned above, the lower reaches of the river had been investigated by Navy Lieutenant George M. Stoney while he was on assignment with Healy in 1883. Both Healy and Stoney determined that the Kowak needed exploration. The Revenue Marine Service gave Healy orders to outfit an expedition, which fell into the hands of Cantwell, and the Navy outfitted Stoney for the same task. During both years (1884 and 1885), Cantwell was going downriver as Stoney was making his way upriver. Stoney, like Cantwell, published an account of his explorations, but not until 14 years later (Stoney, 1900).

\section{REFERENCES}

Cantwell, J.C. 1887. A narrative account of the exploration of the Kowak River, Alaska. In: Healy, M.A. Report of the cruise of the Revenue Marine steamer Corwin in the Arctic Ocean in the year 1885. Washington, D.C.: Government Printing Office. $21-52$.

- 1889a. A narrative account of the exploration of the Kowak River, Alaska. In: Healy, M.A. Report of the cruise of the Revenue Marine steamer Corwin in the Arctic Ocean in the year 1884. Washington, D.C.: Government Printing Office. $49-74$.

- 1889b. Exploration of the Kowak River, Alaska: Ethnological notes. In: Healy, M.A. Report of the cruise of the Revenue Marine steamer Corwin in the Arctic Ocean in the year 1884. Washington, D.C.: Government Printing Office. $75-98$.

— 1896. Ice-cliffs on the Kowak River. National Geographic Magazine 7:345-346.

- 1902. Report of the operations of the U.S. Revenue steamer Nunivak on the Yukon River Station, Alaska, 18991901. Washington, D.C.: Government Printing Office.

- 1935. Captain Healy's reindeer. The Marine Corps Gazette 20:26-29, 58-60.

Cantwell, J.C., and Yemans, H.W. 1889. In: Healy, M.A. Report of the cruise of the Revenue Marine steamer Corwin in the Arctic Ocean in the year 1884. Washington, D.C.: Government Printing Office. 37-43.

Frantz, H.W. 1940. Spirit of the Coast Guard. U.S. Coast Guard Alumni Association Bulletin 2(10):1-6.

Healy, M.A. 1889. Report of the cruise of the Revenue Marine steamer Corwin in the Arctic Ocean in the year 1884. Washington, D.C.: Government Printing Office.

Murphy, J. 1968. Cutter captain: The life and times of John C. Cantwell. PhD dissertation, University of Connecticut. 265 p.

Stoney, G.M. 1900. Naval explorations in Alaska. Annapolis, Maryland: U.S. Naval Institute.

Strobridge, T., and Noble, D. 1999. Alaska and the U.S. Revenue Cutter Service 1867-1915. Annapolis, Maryland: Naval Institute Press. 223 p.

H. Jesse Walker AINA Fellow and Boyd Professor Emeritus Louisiana State University Baton Rouge, Louisiana 70803, USA hwalker@lsu.edu 